\section{Human milk in the modern world}

Sir,

In her recent review of our book Mavis Gunther (whose work we have admired greatly) seems to have cast us as a blend of brainless (if amiable) zealots, fundamental evangelists, and self-deluded visionaries.

Perhaps our strong secular advocacy is because our perspectives are very different from hers. Our main concerns are with disadvantaged communities (mainly in the third world), where breast feeding is vital for survival in early childhood, rather than ideal as in industrialised parts of the world.

Dr Gunther has misconstrued several concerns expressed by us. For example, the phrase 'statutory legislation for breast feeding' used in her review suggests forced breast feeding camps. In fact, in our book we discuss the legislation that is needed to make it easier for working women to breast feed should they wish to do so-scarcely wild-eyed evangelism, as this is already the practice in some parts of the world.

In essence, what may be called a Calcutta-eye view of infant feeding is very different from a London-eye view. In the third world breast feeding is one of the main components of primary health care in relation to nutrition, water supply, infection, economics, self sufficiency in food production, and child spacing ${ }^{1}$ and as such it deserves activist advocacy.

\section{Reference}

1 Jelliffe D B, Jelliffe E F P. Breast feeding and primary health care: a post-Alma Ata view. Ecology of Food and Nutrition, 1980; 9: 189.

\section{B Jelliffe and E F P Jelliffe School of Public Health, Division of Population, Family, and International Health, Los Angeles, California 90024, USA}

Dr Gunther comments:

I hope that the Jelliffes can bring themselves to read my review again. My words were 'statutory powers to enable working mothers to feed their babies' which to me mean that the choice remains with the mother. Surely we are saying the same thing?

MAVIS GUNTHER 77 Ember Lane, Esher, Surrey KT10 8EG

\section{Treatment of hypophosphataemic vitamin D-resistant rickets}

Sir,

We read with interest the paper by Seino et al. ${ }^{1}$ Our experience with 1- $\alpha$-hydroxy-vitamin $\mathrm{D}_{3}\left(1 \alpha \mathrm{OHD}_{3}\right)$ in the treatment of this disease is limited to one patient-a 2 -year-old girl. The diagnosis was based on rickets, hypophosphataemia, raised alkaline phosphatase, normal serum calcium, and normal serum parathyroid hormone. She has been treated for 2 months with daily administration of $0.5 \mu \mathrm{g} 1 \alpha \mathrm{OHD}_{3}$ and about $2 \mathrm{~g}$ phosphate. Radiological examination already shows partial healing of bone (Figure, $a$ and $b$ ).

Contrary to Seino et al. we have only used small doses of $1 \propto \mathrm{OHD}_{3}$ and we are astonished that the high doses used by them should be necessary, particularly as the risk of side effects and the cost of the treatment are increased.

\section{Jan H Kristiansen and Vibeke Faurholt Pedersen Department of Paediatrics, Odense University Hospital, 5000 Odense, Denmark}

\section{Reference}

1 Seino $\mathrm{Y}$, Shimotsuji $\mathrm{T}$, Ishii $\mathrm{T}$, et al. Treatment of hypophosphataemic vitamin $\mathrm{D}$-resistant rickets with massive doses of 1- $\alpha$-hydroxy-vitamin $D_{3}$ during childhood. Arch Dis Child 1980; 55: 49-53.

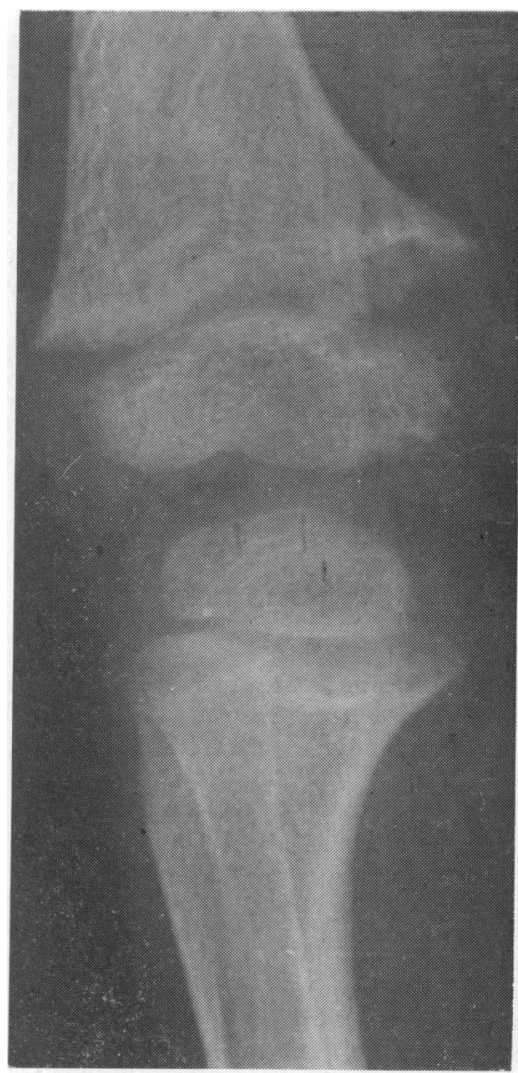

(a)

Figure Roentgenograms of right knee, showing the changes in bone structure. (a) Before treatment, and (b) after 2 months' treatment. 